The Malleable Brand: The Role of Implicit Theories in Evaluating Brand Extensions

\author{
ERIC A.YORKSTON \\ JOSEPH C. NUNES \\ SHASHI MATTA*
}

*Eric A. Yorkston is Associate Professor of Marketing at the Neeley School of Business, Texas Christian University, Box 298530, Fort Worth, TX 76129. Joseph C. Nunes is Associate Professor of Marketing at the Marshall School of Business, University of Southern California, Los Angeles, CA 90089-0443. Shashi Matta is Assistant Professor at Fisher College of Business, Ohio State University, Columbus, OH 43210. Questions should be directed to either Eric A. Yorkston at e.yorkston@tcu.edu or Joseph C. Nunes at jnunes@marshall.usc.edu. 


\title{
The Malleable Brand: The Role of Implicit Theories in Evaluating Brand Extensions
}

\begin{abstract}
This research documents how implicit theories regarding personality traits (whether they are deemed fixed or malleable) affect consumer inferences about the malleability of a brand's personality traits and thus its ability to extend into new categories. In Study 1, we document how consumers who believe traits are malleable (incremental theorists) are more accepting of brand extensions than consumers who believe traits are fixed (entity theorists). These results hold whether implicit theories are measured or manipulated. In Study 2, we show how implicit theories affect consumers' perceptions regarding the flexibility of a brand's personality traits and not its physical traits. Study 3 reveals how consumers primed with different implicit theory orientations respond differently to varying degrees of change within a single trait. This study tests the limits of the effect as well as demonstrates the impact of utilizing primes embedded within standard marketing communication.
\end{abstract}

KEYWORDS: brand extensions, brand personality, branding, implicit theories, marketing communications 
Brands are widely considered the most important assets of a firm (Keller 1993). A significant part of a brand's value or brand equity comes from its contribution in launching new products (Smith and Park 1992). With the cost of introducing an entirely new brand often being prohibitively high, brand extensions represent a strategic tool marketing managers use to exploit that asset; it is estimated that as many as 8 out of 10 new product introductions are brand extensions (Ourusoff et al. 1992). Yet brands are complex entities, and some extensions are inexplicably more successful than others. Not surprisingly, the extent to which a given brand transfers into various other categories successfully has generated high levels of managerial and academic interest (Desai and Keller 2002).

There are a great number of factors that determine the extent to which a brand extension will be embraced by consumers. One factor widely recognized as impacting its success is the degree of "fit" between the extension and the parent brand (Gürhan-Canli 2003; Völckner and Sattler 2006). We focus on perceptions of fit because prior research indicates that categorization judgments and the transfer of parent brand associations are particularly affected by consumers' perceptions of fit (Morrin 1999). Researchers exploring perceived fit have relied on a variety of measures, including feature-based or attributebased similarity (Aaker and Keller 1990; Boush and Loken 1991; Loken and John 1993; Van Osselaer and Alba 2003; Zhang and Sood 2002), brand-specific associations (Broniarczyk and Alba 1994), and goal congruency (Austin and Vancouver 1996; Martin and Stewart 2001). Fit has also been explored at the category level. When the extension category is the same or similar to the parent category and the fit is high, an affect transfer process is believed to occur such that extension attitudes are likely to be based on attitudes toward the parent brand (Aaker and Keller 1990; Boush and Loken 1991; Keller and Aaker 
1992; Kirmani, Sood, and Bridges 1999; Park, Milberg, and Lawson 1991). When the categories vary, researchers have compared extensions and the parent brand's existing product classes by assessing whether they can share the same usage context, can serve as substitutes for each other, and can utilize the same manufacturing skills accrued by the firm (Aaker and Keller 1990; Park, Milberg, and Lawson 1991).

While much is known about how brand, product, category, and firm differences impact brand extensions, considerably less is known about the effect of consumer-level differences on perceived fit and brand extension success. In this research, we examine the impact of a significant consumer-based difference - one's "implicit theory" of the self - on consumers' perceptions of brand extension fit. A growing literature in psychology supports the notion that people possess implicit theories about the malleability of their own personality traits and that these implicit theories affect the inferences made when judging the traits of others (Dweck, Chiu, and Hong 1995a). As such, people tend to adopt one of two theories: either traits are dispositional, fixed entities that cannot change (entity theorists) or traits are situational, dynamic, and able to change with time and effort (incremental theorists). If implicit theories determine whether the personality traits of an individual are considered fixed or malleable, we expect them to do the same with regard to the personality traits of a brand.

Brand personality refers to the "set of human characteristics associated with a brand" (Aaker 1997, p. 347). Brand research has emphasized the impact of brand personality on product evaluation through the endowment of human characteristics and traits. These brand personality traits have been distinguished from the more utilitarian function implied by tangible, product-related attributes (Aaker 1997; Keller 1993). Aaker 
developed and validated a framework to describe and measure what she found to be the 42 traits that comprise the 5 core dimensions of brand personality: sincerity, excitement, competence, sophistication, and ruggedness. A significant stream of empirical work utilizing Aaker's framework has emerged supporting its use as a valid measure of the brand personality construct (Diamantopoulos, Smith, and Grime 2005).

If consumers imbue brands with human personality (Aaker 1999) and people make inferences about the traits of others based on their implicit theories of the self, then we expect consumers to make similar inferences about the traits of brands. In other words, entity theorists, who view personality as fixed, would be less accepting of a brand's ability to change. Therefore, we expect entity theorists to be less accepting of a brand's attempts to extend into a new, dissimilar category than incremental theorists, who view traits as more flexible. This occurs when the brand's positioning in the new category is incongruent with its personality. We test these predictions and their implications directly. By doing so, this work offers a number of valuable insights into understanding the evaluation of brand extensions and the role brand personality and implicit theories play in this process.

The rest of this manuscript is organized as follows. The next section outlines the relevant research on brand extensions. This is followed by a brief introduction to implicit theories along with a discussion of how this particular consumer-level variable can affect perceptions of brand personality and in turn brand extensions. Specific hypotheses about the nature of the effect and the process involved are proposed and tested in a series of studies. In Study 1, we document how consumers who believe traits are malleable (incremental theorists) are accepting of a broader set of brand extensions than consumers who believe these traits are fixed (entity theorists). We also demonstrate how implicit 
theories can be situationally activated and thus potentially useful as a managerial tool. In Study 2 , we examine the underlying process. This study reveals how implicit theories affect judgments by influencing the extent to which a change in the brand's personality rather than a change in the brand's attributes or physicality is acceptable. In Study 3, we utilize advertising text as a less obtrusive prime, which increases the external validity and robustness of our results. In addition, we show how implicit theories determine the degree of change that's acceptable along a single dimension of brand personality. We conclude by discussing managerial implications and some limitations of this work before proposing opportunities for future research.

\section{BRAND EXTENSION RESEARCH}

During the past 15 years, more than 50 studies have been published on brand extensions in the marketing literature. A broad classification of the main research streams can be made on the basis of research that has investigated the antecedents of brand extension evaluation, the process, and the consequences. The research examining antecedents and the process of brand extension evaluation can be further classified into: (1) research on various conceptualizations of perceived fit or similarity, (2) studies of the effects of context variables, (3) studies of communication strategies for brand extension success, and (4) investigations of consumer level differences. Our research explores an as yet unexamined consumer level difference - implicit theories of the self - and its affect on perceptions of brand extension fit.

To date, studies of consumer level differences have focused on four key variables: motivation, expertise, innovativeness, and most recently self-construal. Previous research has found a moderating effect of motivation on the transfer of both knowledge and affect 
from a parent brand to an extension and thus brand extension fit (Gürhan-Canli and Maheswaran 1998). Under high-motivation conditions, consumers engage in elaborate cognitive processing and consider information about the extension in a piecemeal fashion. In contrast, under low-motivation conditions, cognitive processing is less elaborate and more categorical and therefore greater transfer of affect occurs between the parent brand and the extension. Expertise has also been shown to moderate the effect of brand associations, brand affect, and fit on brand extension attitude (Broniarczyk and Alba 1994). Experts' evaluations are based on the processing of product-related associations whereas those of novices are based on perceptions of fit and attitude toward the brand. The third consumer level variable already studied has been labeled consumer innovativeness and product adoption tendency (Klink and Smith 2001). Early adopters have been shown to be less sensitive to risk. Consequently, perceived fit is less important in their evaluation of an extension as compared to late adopters. Finally, most recently Ahluwalia (2008) explored how consumers who have a more interdependent self-view (i.e. more flexible view of relationships) may more easily uncover relationships between an extension and its parent brand, fostering perceived fit. The findings suggest consumers found to be high in interdependent self-construal or be relational thinkers will view brand stretches more positively, but only when they are motivated to employ their superior relational abilities to unearth connections. By studying the impact implicit theories have on the evaluation and acceptability of brand extensions, we introduce a fifth essential consumer level variable into the mix. 


\section{IMPLICIT THEORIES OF THE SELF}

The role of implicit theories of the self in the interpretation and understanding of human behavior is gaining increasing acceptance among cognitive and social psychologists. Dweck et al. (1995a) have identified two distinct implicit theories that refer to assumptions people make about the malleability of personality, intelligence, and morality and have been shown to influence a variety of judgments about the self and about others.

Research in this area has consistently found that entity theorists believe ability, intelligence (Butler 2000), and moral character (Chiu et al. 1997) are fixed, whereas incremental theorists believe these aspects can change. For example, entity theorists are likely to believe that intelligence is a fixed trait, and though people can learn new things, their underlying intelligence remains the same. In contrast, incremental theorists are likely to believe that individuals may become more intelligent through their efforts.

People call upon their implicit theories regarding personality traits to interpret, explain, and predict human behavior (Hong, Levy, and Chiu 2001). In other words, entity theorists believe that knowing a person's traits allows one to make confident predictions about that person's behaviors in new situations and knowing how one behaved in the past allows one to make confident inferences about this person's traits. Conversely, incremental theorists are less prone to such rapid, global evaluations. For them, really knowing a person would involve seeing him or her over and over again (Dweck et al. 1995a). In other words, entity theorists rely on initial trait information when making causal attributions or making subsequent judgments, while incremental theorists focus less on dispositional factors and more on psychological or behavioral mediators such as the individual's needs, emotions, 
goals, or intentions. A significant outcome of these divergent viewpoints is that prior beliefs remain more stable for entity theorists than incremental theorists, with the former more likely to construe a purported personality change negatively.

The notion of brand personality ascribes human characteristics to brands based on the premise that brands can have personality traits in much the same way as humans. Plummer (1985) argued that brand traits can be formed by direct or indirect contact with the brand. In the direct way, brand personality is formed by the people associated with the brand, such as the prototypical user, the company's CEO, or endorsers. In the indirect way, brand personality is formed considering product-related attributes, product category associations, and other marketing mix variables affected by advertising and product packaging such as the brand's name, symbol and logo, advertising style, price, and distribution channel (Batra, Lehmann, and Singh 1993). Consequently, consumers often think of brands as if they were famous people, celebrities, or historical figures (Rook 1985). Just as consumers make inferences regarding the malleability of their own and other people's personality traits, we expect consumers to make inferences about the malleability of a brand's personality traits. Hence, a particular brand extension might be seen as a better or worse fit with the parent brand based on the individual's implicit theory of the self.

We hypothesize that, ceteris paribus, consumers who are entity theorists will perceive a brand's personality as being less malleable and therefore will be less accepting than incremental theorists of extensions that necessitate a change in brand personality. This difference should surface when consumers evaluate brand extensions in various categories that differ in their perceptual distance from the parent brand. Thus, incremental theorists 
will find a brand to be more malleable and therefore able to "stretch" further (i.e. into more diverse categories). Stated more formally:

H1: Incremental theorists will deem a greater number of brand extensions for a particular brand as viable as compared to entity theorists.

We test Hypothesis 1 in Part I of Study 1. What makes our theorizing much more important for managers is the notion that one's implicit theory orientation is itself susceptible to influence. Given the extant literature in social psychology suggesting this is the case, we hypothesize:

H2: Individuals primed to believe that people can change (incremental orientation) will deem a greater number of brand extensions for a particular brand as viable as compared to those individuals primed that people cannot change (entity orientation).

We test Hypothesis 2 directly in Part II of Study 1.

One goal of this research is to demonstrate how implicit theories affect beliefs about the malleability of a brand's personality traits just as they affect beliefs about a human's personality traits. While brands are inanimate objects, they can be imbued with personality traits, so the personality metaphor seems suitable in many ways. Dweck et al. (1995a, 1995b) found that implicit theories regarding nonhuman entities with human-like attributes (e.g. the malleability of the world) have the same format as their implicit person theory measures. This leads to Hypothesis 3 :

H3: Implicit theories impact the perceived malleability of a brand by affecting the perceived malleability of a brand's personality and not its physicality.

Hypothesis 3 is tested directly in Study 2. Finally, the idea that some people adopt a dynamic approach to understanding people (incremental theorists) may derive from a different processing framework, but it does not imply that change can be unlimited. Although incremental theorists are more willing to accept a change in a brand's personality 
than entity theorists, we suspect too great a change may violate their boundaries as well. This leads us to Hypothesis 4:

H4: Too great a change in personality will violate an incremental theorist's latitude of acceptability and result in a response similar to that garnered from entity theorists.

Hypothesis 4 and the boundaries to utilizing implicit theory primes are tested in Study 3.

Taken together, these four hypotheses help explain how consumers process brand extensions and make judgments regarding a parent brand and its brand extensions. Our studies are not only applicable to managers interested in segmenting consumers based on their ability to accept change, but they demonstrate how managers can directly affect how accepting consumers are of change through its advertising (Study 3). We begin by demonstrating the impact of implicit theories on brand extension acceptance in Study 1 and move toward inducing implicit theory orientations with marketing materials in Study 3.

\section{STUDY 1: IMPLICT THEORIES AND THEIR EFFECT ON BRANDS}

In Study 1, we investigate whether incremental theorists, who see their own personality traits as more malleable, are more accepting of brand extensions for a particular parent brand than entity theorists. In this way, Study 1 is a direct test of Hypotheses 1 and 2.

\section{Method}

Sample, Design, and Procedure. This study consists of two separate parts, both utilizing a 2 (implicit theory orientation: entity vs. incremental) x 5 (product category) design, where the second factor is a repeated measure. In Part I, participants included 125 undergraduate students enrolled in an introductory marketing course at a large, West Coast university. In order to categorize respondents according to their dispositional implicit theory orientation, 
participants in Part I completed the Implicit Person Theories Measure (Levy, Stroessner, and Dweck 1998). Each respondent was given a list of five popular brands from five different categories (Dreyer's ice cream, OshKosh B'Gosh children's clothing, Sketchers sneakers, Nokia cell phones, and Paper Mate pens) with five proposed extensions (e.g. Nokia Extensions: PDA, desktop computer, laptop, tablet PC, and digital camcorder). The extensions were pre-tested such that they varied in their perceptual distance from the parent brand. Respondents were asked to choose as many of the proposed extensions as they thought would "fit" well with the existing brand. The number of product extensions they chose for each brand was employed as the dependent measure.

In Part II, participants were an independent sample of 124 undergraduate students from the same subject pool at the same university. We again utilized a 2 (implicit theory orientation) x 5 (product category) design where the second factor was a repeated measure consisting of the brands Ivory soap, Starbucks coffee, Yamaha motorcycles, Nokia cell phones, and Paper Mate pens. These extensions were also pre-tested such that they varied in their perceptual distance from the parent brand. Unlike Part I in which participants' dispositional implicit theory was measured, in Part II, implicit theory orientation was situationally activated using the general trait manipulation utilized in Chiu, Hong, and Dweck (1997). Participants were told they were being tested on reading comprehension and memory. They were instructed to read a paragraph containing concepts about which they would be tested on later in the session. The critical excerpt for the entity theory orientation prime reads as follows:

In his talk at the American Psychological Association's annual convention held at Washington D.C. in August, Dr. George Medin argued that "in most of us, by the age of ten, our character has set like plaster and will never soften again." 
He reported numerous large longitudinal studies which show

that people "age and develop, but they do so on the

foundation of enduring dispositions." He also reported

research findings showing that people's personality

characteristics are fixed and cannot be changed.

The critical excerpt for the incremental theory orientation prime reads as follows:

In his talk at the American Psychological Association's annual convention held at Washington D.C. in August, Dr. George Medin argued that "no one's character is hard like a rock that cannot be changed. Only for some, greater effort and determination are needed to effect changes." He reported numerous large longitudinal studies, which show that people can mature and can change their character. He also reported research findings showing that people's personality characteristics can be changed even in their late sixties.

Participants subsequently completed an unrelated filler task intended to erase their memory of the paragraph. They then turned to the focal task in which they chose as many of the proposed extensions as they thought would "fit" well with the existing brand. Again, the number of product extensions they chose for each brand served as the dependent measure. As a manipulation check, participants in Part II completed the Implicit Person Theories Measure as well (Levy et al. 1998).

\section{Results}

Brand Extension Acceptability - Part I. A median split was utilized to divide participants from Part I into two groups based on their responses to the Implicit Person Theories Measure $(\alpha=.93 ; M=27.9 ;$ Median $=28)$. A 2 (implicit theory orientation) $\times 5$ (product category) ANOVA, with the latter factor being a within-subjects repeated measure, revealed that individuals with a chronically accessible incremental theory orientation (i.e., incremental theorists) were accepting of more brand extensions than individuals who possessed a chronically accessible entity theory orientation $\left(\mathrm{M}_{\text {Incremental }}=2.77\right.$ vs. $\mathrm{M}_{\text {Entity }}=$ 
$1.53, \mathrm{~F}(1,123)=64.36, p<.01)$. There was a significant effect among brand categories $(\mathrm{F}(4,120)=5.30, p<.01)$ such that Paper Mate pens and Dreyer's ice cream were thought to be less extendible than the other parent brands. No interaction effects between individual brands and implicit theory orientation were observed. Individual ANOVAs of implicit theory orientation on brand extensions for each of the five brands reveal the same pattern of differences between incremental and entity theorists $(\mathrm{F}(1,123)=68.52,51.69,37.74,24.34$, 15.14 , all $p$ 's $<.01)$. Table 1 presents the results for each brand. In summary, in Part I of Study 1, we find evidence that a difference in chronic implicit theory orientation affects judgments regarding the acceptability of brand extensions.

Insert Table 1 about here

Brand Extension Acceptability - Part II. The analysis for Part II was similar to Part I, but respondents were sorted according to which prime they read and the Implicit Person Theories Measure results were utilized as a manipulation check. As expected, the manipulation of implicit theory orientation was successful. Participants exposed to the entity orientation prime differed significantly from those exposed to the incremental orientation condition on the Implicit Person Theories Measure $\left(\alpha=.91, \mathrm{M}=28.6\right.$, Median $=28, \mathrm{M}_{\text {Entity }}=30.10 \mathrm{vs}$. $\left.\mathrm{M}_{\text {Incremental }} 27.13, \mathrm{~F}(1,122)=4.54, p<.05\right)$. A repeated measures ANOVA of implicit orientation prime (entity vs. incremental) on the number of acceptable brand extensions revealed a main effect of the general trait manipulation $(\mathrm{F}(1,122)=30.51, p<.01)$. Individuals who were primed to believe traits are malleable believed the brands were capable of more brand extensions than individuals who were primed to believe traits are fixed $\left(\mathrm{M}_{\text {Incremental }}=1.89\right.$ vs. $\left.\mathrm{M}_{\text {Entity }}=1.30\right)$. A brand category effect was again significant $(\mathrm{F}(4,119)=$ 
$5.27, p<.01)$ as some brands - specifically Yamaha and Nokia - were seen as more extendable than others. There were no interaction effects between brand category and implicit theory orientation ( $p>.15$ ). Again, the results hold for each individual brand (see Table 2).

Insert Table 2 about here

\section{Discussion}

The results from Part I of Study 1 support Hypothesis 1 by illustrating how one's dispositional implicit theory orientation applies to brands. It appears that the more malleable one sees an individual's traits, the more likely one is to see a brand as being malleable. This malleability is reflected in the endorsement of a greater number of brand extensions. In Part II of Study 1, we manipulated rather than measured people's implicit theory orientation utilizing the generalized trait manipulation used in social psychological research. Consistent with Hypothesis 2, we find that activating a generalized belief can affect how malleable consumers believe brands can be. Knowing that implicit theories can be primed, which in turn affects the acceptability of brand extensions, makes these results especially relevant for marketing managers. As will be shown in Study 3, persuasive advertising communication can result in consumers believing a brand is more malleable or more fixed with respect to its traits. Taken together, Parts I and II of Study 1 contribute to our understanding of branding by demonstrating how consumers' individual beliefs regarding the malleability of personality traits can impact consumers' evaluations of brand extensions.

In Study 2 we delve into the process. We demonstrate how implicit theories affect beliefs about the personality traits associated with brands rather than beliefs about the 
physicality of the brand. Study 2 reveals that implicit theories operate by affecting beliefs regarding the malleability of a brand's traits which, in turn, motivate either more positive or negative interpretations of a brand extension's perceived fit with the parent brand.

\section{STUDY 2: PERSONALITY \& PHYSICALITY CONGRUENCE}

Aside from sharing physical attributes, perceived fit has been explored by assessing whether the parent brand and extension share the same usage context, can serve as substitutes for each other, and can utilize the same manufacturing skills in production. While previous studies (Bridges, Keller, and Sood 2000) have explored fit both as a function of attribute similarity (i.e. physical traits) and abstract concepts such as cohesion (e.g. both are products targeted to children), in this study we demonstrate how perceptions of fit are affected by similarities and differences in personality traits. In doing so, we not only identify a new aspect of perceived fit but show how implicit theories, studied exclusively in the domain of human personalities, affect brand personalities.

\section{Method}

Sample, Design, and Procedure. Participants were 150 students at a large, Southwestern university. A 2 (implicit theory orientation) x 2 (personality trait congruence) x 2 (physicality congruence) $\times 2$ (parent brand) design was employed with the first three factors manipulated between subjects and parent brand as a within subjects replication. The parent brands were Subaru, the Japanese auto manufacturer owned by Fuji Heavy Industries Ltd., and Tiffany \& Company, the American jeweler and design house. We utilized two different parent brands to replicate the effect in this study solely to show the generalizability of our results across divergent brands and categories; all results reported below hold for each individual brand. 
Brand personality traits were drawn from the five distinct dimensions (sincerity, excitement, competence, sophistication, and ruggedness) identified by Aaker (1997). A pilot study utilizing Aaker's Brand Personality Scale found that Subaru excelled on ruggedness (this dimension rated significantly higher than the four others for this brand) while Tiffany \& Co. excelled, in like fashion, on sophistication. We intentionally chose brands that excelled on ruggedness and sophistication because these two dimensions of brand personality differ from the "Big Five" traits of human personality (Briggs 1992).

A number of products were pilot tested in order to identify a set for each brand that allowed us to vary physicality and personality congruence independently. Results revealed extensions into categories where the new product included engine technology would be physically congruent for car maker Subaru, while the absence of engine technology would not. Similarly, products incorporating silver would be physically congruent for jeweler Tiffany \& Co. while products incorporating leather would not. With respect to personality, wilderness water products (kayaks and jet skis) were deemed significantly more rugged and hence more congruent with Subaru's rugged personality than urban terrestrial products (skateboards and scooters). High heel shoes were seen as significantly more sophisticated than flats and thus more congruent with Tiffany \& Co.'s sophisticated personality. The parent brands, brand extensions, and the manifest congruencies are listed in Table 3.

Insert Table 3 about here

The focal task in the main study asked respondents to read separate summaries describing Subaru and Tiffany \& Co. before answering questions about the parent brands and potential brand extensions. Each respondent was presented with an extension that was 
either congruent with respect to the parent brand's physicality, its personality, neither, or both, depending on the condition. Our dependent measure was intended to capture whether a "consumer perceives the item to be consistent with a parent brand," otherwise referred to as perceptual fit, as it is a key in predicting brand extension success (Tauber 1988;

Völckner and Sattler 2006). Respondents were asked to evaluate the proposed extension based on how well it "fit" with the parent brand on a 5-point scale anchored with "does not fit at all" and "fits very well."

As a manipulation check, respondents evaluated both parent brands (Subaru and Tiffany \& Co.) as well as each extension on Aaker's (1997) five personality dimensions. This was done utilizing the 15 personality sub-factors and providing a five-point measurement scale for each $(1=$ not at all descriptive, $5=$ extremely descriptive $)$. Participants' final task was to complete the Implicit Person Theories Measure before being debriefed and dismissed.

\section{Results}

Brand Extension Personality: A Manipulation Check. A brand personality score for each of the "big five" main personality dimensions was created for each parent brand and each extension (see Table 4). For both brands and all extensions, Cronbach's $\alpha$ on all dimensions exceeded the standard threshold of .7 (Nunnally 1978) except for the traits of sincerity and sophistication for Tiffany \& Co.'s silver-buckled work flats ( $\alpha$ 's of .65 and .62, respectively). The lower-than-expected correlations for this extension did not influence any results presented here and thus were not a concern. In addition, somewhat lower alphas (e.g. in the .60-.69 range) are commonly acceptable if there are only a small number of items in the scale (Morgan, Gliner, and Harmon 2005, p. 286). 
Insert Table 4 about here

These measures were used to confirm that the extensions evaluated varied in terms of their congruence personality-wise with the parent brand (e.g. kayaks and jet skis were perceived as significantly more rugged than skateboards and scooters). A 2 (physicality congruence) x 2 (personality trait congruence) $\times 2$ (parent brand) repeated measures ANOVA on the manipulated brand extension dimensions (i.e. ruggedness for Subaru and sophistication for Tiffany \& Co.) with parent brand as a within-subject repeated measure served as a brand personality manipulation check. The significant main effect of brand personality $(\mathrm{F}(1,148)=21.42, p<.01)$ supports our manipulation of the personality dimensions. Wilderness water extensions were seen as more rugged than urban terrestrial extensions for Subaru $\left(\mathrm{M}_{\text {Wilderness }}=4.05\right.$ vs. $\left.\mathrm{M}_{\text {Urban }}=3.22 ; \mathrm{F}(1,142)=16.10, p<.01\right)$ and high heel shoes were more sophisticated than work flats for Tiffany \& Co. $\left(\mathrm{M}_{\text {Heels }}=4.10\right.$ vs. $\left.\mathrm{M}_{\text {Flats }}=2.85 ; \mathrm{F}(1,142)=8.47, p<.01\right)$. Additionally, the main effect of physical attribute congruence was not significant $(\mathrm{F}(1,142)=3.42, p>.05)$ indicating that our physical trait manipulation (i.e. Subaru: motorized vs. non-motorized; Tiffany \& Co.: silver vs. leather) did not influence participants' evaluations of the brand extensions' personality traits (ruggedness and sophistication).

Brand Extension \& Perceived Fit. As in Part I of Study 1, we relied on chronic implicit theory orientation rather than activated differences in this study. A median split was utilized to divide participants into two groups based on their responses to the Implicit Person Theories Measure $(\alpha=.86 ; \mathrm{M}=30.0 ;$ Median =30). A 2 (physicality congruence) x 2 (personality trait congruence) x 2 (implicit theory orientation) x 2 (parent brand) 
ANOVA was conducted on perceived fit with parent brand as a within-subject factor. Main effects of both physicality congruence $(\mathrm{F}(1,140)=11.69, p<.01)$ and personality trait congruence $(\mathrm{F}(1,140)=33.90, p<.01)$ were significant. The first effect $\left(\mathrm{M}_{\text {Congruent-physical }}=\right.$ 2.91 vs. $\mathrm{M}_{\text {Incongruent-physcial }}=2.44$ ) is consistent with past work on brand extensions that suggests congruency on physical attributes matters. The main effect of personality trait congruence supports our hypothesizing by showing how personality traits affect perceptions of brand extension fit $\left(\mathrm{M}_{\text {Congruent-personality }}=3.02 \mathrm{vs.} \mathrm{M}_{\text {Incongruent-personality }}=2.33\right)$.

More important for the purposes of this research, the interaction between implicit theory orientation and brand personality congruence was significant $(\mathrm{F}(1,140)=4.16, p<$ .05 ), while the interaction between implicit theory orientation and physical attributes was $\operatorname{not}(\mathrm{F}(1,140)=1.42, p>.24)$. As Figure 1 illustrates, while both incremental and entity theorists could see fit when an extension's personality traits were congruent with the parent brand $\left(\mathrm{M}_{\text {Incremental }}=2.96\right.$ vs. $\left.\mathrm{M}_{\text {Entity }}=3.07\right)$, entity theorists were less willing to "stretch" the personality dimension in order to see fit between incongruent brand extension personalities $\left(\mathrm{M}_{\text {Incremental }}=2.59\right.$ vs. $\left.\mathrm{M}_{\text {Entity }}=2.08 ; \mathrm{F}(1,140)=6.85, p<.05\right)$. In other words, consistent with Hypothesis 3, incremental theorists were more accepting than entity theorists of larger changes in personality traits exemplified through less rugged (scooters, skateboards) or less sophisticated (flats) extensions.

Insert Figure 1 about here

It is worth noting that the interaction effect between physical attribute congruence and brand personality congruence $(\mathrm{F}(1,140)=6.98, p<.05)$ and the 3 -way interaction between implicit theory, personality congruence, and physicality congruence $(\mathrm{F}(1,140)=$ 
$7.22, p<.05)$ were significant. The 2-way interaction is best understood in light of the 3way interaction (see Figure 2). When physical attributes were congruent (i.e., motorized extensions for Subaru and silver buckles for Tiffany \& Co.), only entity theorists took issue with personality incongruent extensions, the distinctly less rugged scooter/skateboard for Subaru and the unsophisticated flats for Tiffany \& Co. Incremental theorists rated the fit for these products as highly as the more rugged jet ski and sophisticated high heel shoes (Figure 2, Panel A). However, when the goods were physically incongruent (non-motorized and leather), personality incongruence (kayaks and flats) resulted in lower levels of perceived fit for both incremental and entity theorists (Figure 2, Panel B).

This result suggests that for incremental theorists, who are typically more accepting of changes in personality traits, a double hit of both personality and physical incongruence was enough to impact their perceptions of parent-extension fit. Incremental theorists are more tolerant of personality incongruence (Panel A) except when the added physical incongruence (Panel B) makes the brand extension seem too far of a stretch (i.e. too big a change). Plaks, Grant, and Dweck (2005) found that implicit theory violation creates a "warm state," wherein individuals are motivated to protect their activated theory in the face of disconfirming evidence. Violations should therefore engender negative attitudes toward an extension that goes too far as attempts to maintain cognitive consistency between a parent brand and its extension are thwarted. Although incremental theorists are more willing to stretch a brand's personality traits than entity theorists, too much change physical and personality incongruence - can be too much even for them. We will test this interpretation explicitly in Study 3. 
Insert Figure 2 about here

We should also note that we observed a within subjects effect of parent brand $(\mathrm{F}(1,140)=21.31, p<.01)$ in which, overall, Subaru was seen as more extendable than Tiffany \& Co. $\left(\mathrm{M}_{\text {Subaru }}=2.95\right.$ vs. $\left.\mathrm{M}_{\text {Tiffany }}=2.39\right)$. In addition, there was a significant parent brand by personality interaction $(\mathrm{F}(1,140)=8.28, p<.01)$. These effects could be driven either by the strength of the parent brands or by the particular choices for brand extensions for this study, but they neither detract from the principal results nor offer much insight into the outcome of interest as the implicit theory results exist for each brand extension studied. Product Category Gender Effects. The target market for Tiffany \& Co. is skewed toward females, while automobiles in general, and Subaru in particular, may be viewed as skewed toward males. Consequently, gender-oriented effects may exist in our data. Our sample consisted of 64 females and 82 males (with 2 participants not supplying gender information). Running the analysis including gender as an additional factor yielded a 2 (gender) $\mathrm{x} 2$ (implicit theory orientation) $\mathrm{x} 2$ (physical congruence $\mathrm{x} 2$ (personality congruence) x 2 (parent brand) design that produced neither a significant gender main effect nor any significant gender interactions. In particular, the brand $\mathrm{x}$ gender interaction did not approach significance $(\mathrm{F}(1,130)=.096, \mathrm{p}=.758)$. While it is likely that attitudes and preferences regarding Tiffany \& Co. and Subaru do indeed differ by gender, perceptions of fit regarding the brands' extensions do not appear to be driven by gender. Respondents, whether male or female, were apparently familiar enough with both brands to make similar judgments. 


\section{Discussion}

The results of Study 2 are consistent with Study 1 in that consumers' responses to potential brand extensions depend on implicit theory orientation. It came as no surprise that congruency on both physical attributes and personality traits are found to affect perceived fit. What is novel in our results is that implicit theories influence perceptions of extension fit by moderating the impact of personality trait incongruence. Results from Study 2 provide direct support for Hypothesis 3 that implicit theories impact the perceived malleability of a brand's personality traits and not its physicality. Hence, just as implicit theories impact how malleable people believe personality traits can be for people, we find that implicit theories impact how malleable personality traits can be for brands.

In Study 2, as we varied congruency for Subaru, the extension categories varied (e.g. jet skis and skateboards) but remained constant for the parent (i.e. cars). Conversely, the extension category remained constant for Tiffany \& Co. (i.e. shoes) while the parent, albeit primarily a jeweler, already offered products in a number of different categories (i.e., barware, eyewear, etc). It could be argued that differences on other category dimensions (e.g. the degree to which parent and extension products are substitutes or complements, whether production skills are more or less transferable, etc.) may have played a role in assessing perceived fit. Given that our results do not change if we analyze either brand separately (i.e., either the parent or extensions cross many categories), we become more confident in our findings. But we acknowledge that we cannot rule out category effects in Study 2. Thus, we address this issue in our next study.

In Study 3, we set out to do a number of things. Recent research ( $\mathrm{Ng}$ and Houston 2006; Mao and Krishnan 2006) argues fit can be based on a category prototype or category 
exemplar. Controlling for categories would help ensure that differing associations of category prototypes in relation to the parent brand category would not be driving perceptions of fit between one brand extension and another. We therefore constrain both the parent (i.e. car companies) and the extension (i.e. sunglasses) to single categories. In addition, we utilize two parent brands that differ only in their perceived ruggedness. By isolating the impact of changes on the single brand personality dimension, ruggedness, we can claim that the differences in the acceptability of extensions are due to this particular aspect of the brand's personality. Further, by comparing extensions that are near, far, and one that pushes the rugged positioning of the extension to the extreme for each brand separately, we reveal a boundary with respect to differences in implicit theories; even incremental theorists have limits regarding how far a particular brand personality can stretch.

Finally, and perhaps most importantly for managers, this study demonstrates how advertising copy can be utilized to invoke either entity or incremental orientations, which clearly demonstrates the practical significance of this research. If a consumer can be placed into a more malleable mindset when initially encoding information regarding a new brand extension, then consumers should be more accepting of the brand extension.

\section{STUDY 3: ADVERTISING EFFECTS ON BRAND EXTENSION FIT}

\section{Method}

Brand Personality Traits Pre-Test. A pre-test identified two brands that differed on only one brand personality trait (ruggedness) and were similar with respect to consumers' brand attitudes and purchase intentions. Respondents were 36 undergraduate business students from a large, West Coast university who were intentionally drawn from the same sample 
population but who did not participate in the main study. These respondents evaluated 38 existing automobile and fashion brand names on Aaker's (1997) five brand personality dimensions as well as provided their overall liking and purchase intentions for these brands on 7-point scales. Mitsubishi and Jeep were found to be the most similar on overall liking $\left(\mathrm{M}_{\text {Jeep }}=4.53\right.$ vs. $\left.\mathrm{M}_{\text {Mitsubishi }}=4.50\right)$, purchase intention, $\left(\mathrm{M}_{\text {Jeep }}=3.74\right.$ vs. $\left.\mathrm{M}_{\text {Mitsubishi }}=3.85\right)$, and four out of the five personality dimensions: $\operatorname{sincerity}\left(\mathrm{M}_{\mathrm{Jeep}}=4.80 \mathrm{vs} . \mathrm{M}_{\text {Mitsubishi }}=\right.$ $4.00)$, excitement $\left(\mathrm{M}_{\text {Jeep }}=4.63\right.$ vs. $\left.\mathrm{M}_{\text {Mitsubishi }}=4.00\right)$, competence $\left(\mathrm{M}_{\text {Jeep }}=4.68\right.$ vs. $\left.\mathrm{M}_{\text {Mitsubishi }}=4.00\right)$, and sophistication $\left(\mathrm{M}_{\text {Jeep }}=3.63 \mathrm{vs.} \mathrm{M}_{\text {Mitsubishi }}=3.16\right.$; all $p$ 's $\left.>.05\right)$. Jeep and Mitsubishi differed significantly only on perceptions of the fifth personality dimension, ruggedness $\left(\mathrm{M}_{\text {Jeep }}=6.53\right.$ vs. $\left.\mathrm{M}_{\text {Mitsubishi }}=2.95\right)$.

Sample, Design, and Procedure. Pre-test results revealed sunglasses would serve as a realistic brand extension for both Jeep and Mitsubishi. They also revealed that Jeep and Mitsubishi did not differ in terms of their perceived competence in making cars or their manufacturing skills (Aaker and Keller 1990). In addition, attitudes toward the brands did not differ significantly (all $p$ 's $>.15$ ). Twelve advertisements for sunglasses were developed that differed on three factors to provide the 12 cells of our 2 (implicit theory: entity versus incremental) x 3 (brand stretch: near, moderate and extreme) x 2 (parent brand: Jeep versus Mitsubishi) full factorial, between-subjects design.

First, the ad copy was altered in order to prime different implicit theories (entity vs. incremental). A block of copy in each ad discussed the malleability of the brand. Pretesting helped us develop effective ad copy that situationally activated either an incremental or entity theory orientation. The incremental theory prime ad copy stated, "At 
Jeep [Mitsubishi], we are evolving. We ask ourselves how we can adapt to fit your lifestyle. You change and Jeep [Mitsubishi] is changing with you." The entity theory prime ad copy stated, "At Jeep [Mitsubishi], we are committed to consistency and unwavering steadfastness. Ask yourself how our rock-solidness can fit your lifestyle. Your personality and ideals stay the same and Jeep [Mitsubishi] stays there with you.”

Second, we varied brand stretch by varying the extension's positioning regarding its ruggedness relative to the parent brand (near, moderate and extreme). Each ad contained the header "Introducing JEEP [MITSUBISHI] brand sunglasses" that introduced the extending brand. Each advertisement included a background picture and one block of ad copy that described the extension on the ruggedness dimension. For Mitsubishi, the copy in the "near" stretch or not very rugged advertisements focused on utilizing the sunglasses for everyday events and contained a picture of a hipster walking his dog. The copy in the "moderate" (i.e., more rugged) and "extreme" (i.e., extremely rugged) stretch conditions focused on utilizing the sunglasses for more rugged adventures such as fishing off the coast of Baja and hiking in the Rockies. These portrayed a recreational fisherman wearing sunglasses while kneeling on shore holding his catch and a rock climber rappelling down a cliff wearing sunglasses, respectively.

Because Jeep was initially seen as more rugged than Mitsubishi $\left(\mathrm{M}_{\text {Mitsubishi }}=2.95\right.$, $\mathrm{M}_{\mathrm{Jeep}}=6.53$ on a 7-point scale), our three conditions varied slightly for this brand. The near stretch included what was deemed a moderate stretch for Mitsubishi: the ad portraying the recreational fisherman holding his catch (see Appendix 1 for an example). The moderate stretch for Jeep included what was an extreme stretch on the rugged dimension for Mitsubishi: the ad displaying the rock climber rappelling down a cliff. For Jeep, the 
extreme stretch ad included a cliff jumper flying in the sky in a glide suit. A pretest in which 54 respondents each evaluated the ruggedness of one of the four advertisements for "Brand X" revealed that each advertisement differed significantly on ruggedness in the predicted order $(\mathrm{F}(3,50)=33.08 ; p<.01)$. Individual contrasts revealed that the ad displaying the Dog Walker $(\mathrm{M}=2.0)$ was less rugged than the ad with the Fisherman $(\mathrm{M}=$ $3.5 ; \mathrm{t}(50)=5.16, p<.01$, one tailed $)$, which was less rugged than the Rock Climber $(\mathrm{M}=$ $4.0 ; \mathrm{t}(50)=1.69, p<.05$, one tailed $)$, which was less rugged than the Skydiver $(\mathrm{M}=4.4$; $\mathrm{t}(50)=1.59, p<.06$, one tailed).

In summary, for two brands that differed in initial perceptions on the trait of ruggedness, we created ads portraying extensions that were either consistent with respondents' perceptions (near stretch), somewhat exaggerated (moderate stretch) or very much exaggerated (extreme stretch). Accordingly, we expected implicit theory and brand stretch to interact such that a near stretch is accepted by entity and incremental theorists alike while an extreme stretch is rejected by both groups. However, for a moderate stretch, we expected incremental theorists to be more accepting than entity theorists. While the stimuli differed due to respondents' initial perceptions of the ruggedness of each brand, the same pattern was predicted to hold for both Jeep and Mitsubishi.

Respondents were 232 undergraduate business students at a large West Coast university. Participants were exposed to only one advertisement and then evaluated the brand extension with respect to its perceived fit on the same scale as in Study 2. They also provided their opinions with respect to the ultimate success of the extension. These two dependent measures were assessed on five-point scales anchored by "does not fit at all" to "fits extremely well" and "not at all successful" to "extremely successful," respectively. As 
a manipulation check, they also evaluated the parent brand on Aaker's (1997) five brand personality dimensions.

\section{Results}

To insure that we only manipulated the personality trait of ruggedness when we alternated the parent brand between Jeep and Mitsubishi, we compared all of the personality dimension measures for the opposing parent brands. The parent brands did not differ on four dimensions (sincerity, excitement, competence, and sophistication), but did differ such that Jeep was seen as significantly more rugged than Mitsubishi $\left(\mathrm{M}_{\text {Jeep }}=4.50\right.$ vs. $\left.\mathrm{M}_{\text {Mitsubishi }}=3.87 ; \mathrm{F}(1,231)=29.80, p<.01\right)$. Similar to the pre-test results referred to earlier, the results from our manipulation check confirmed that varying the parent brand resulted in a change on only a single personality trait: ruggedness.

A 2 (parent brand) x 2 (implicit theory orientation) x 3 (brand stretch) ANOVA on perceptions of fit revealed main effects of all three variables. As expected, Jeep $\left(\mathrm{M}_{\mathrm{Jeep}}=\right.$ 3.40) is a better overall fit for rugged sunglasses than Mitsubishi $\left(\mathrm{M}_{\text {Mitsubishi }}=2.59\right.$; $\mathrm{F}(1,220)=36.59, p<.01)$. This is likely due to Jeep being perceived as more rugged at the onset. Brand stretch also influenced perceptions of fit $(\mathrm{F}(2,220)=35.60 ; p<.01)$. In general, near stretches are more effective such that sunglasses which are a smaller stretch $\left(\mathrm{M}_{\text {Near }}=3.69\right)$ posses a better overall perceived fit than moderate stretches $\left(\mathrm{M}_{\text {Moderate }}=\right.$ $2.97 ; \mathrm{t}(220)=4.03, p<.01)$ or extreme stretches $\left(\mathrm{M}_{\text {Extreme }}=2.32 ; \mathrm{t}(220)=3.38, p<.01\right)$. Also as expected, those primed with the Incremental Implicit Theory ad copy $\left(\mathrm{M}_{\text {Incremental }}=\right.$ 3.14) reported better perceptions of fit than those primed with the Entity Theory copy $\left(\mathrm{M}_{\text {Entity }}=2.85 ; \mathrm{F}(1,220)=4.91, p<.05\right)$. These main effects can be better understood in 
light of the significant 2-way interaction between brand stretch and implicit theory orientation $(\mathrm{F}(2,220)=4.44, p<.01)$.

As shown in Figure 3, it is apparent that neither those respondents primed to be entity theorists nor incremental theorists deemed a near stretch as incompatible, although those who viewed Jeep sunglasses were more approving than those who viewed the Mitsubishi sunglasses $\left(\mathrm{M}_{\text {Entity-Jeep }}=3.80\right.$ and $\mathrm{M}_{\text {Incremental-Jeep }}=3.84$ versus $\mathrm{M}_{\text {Entity-Mitsu }}=3.53$ and $\mathrm{M}_{\text {Incremental-Mitsu }}=3.59$ ). As the ads differed for each level of stretch, and Mitsubishi was initially perceived as less rugged, it is not surprising that we observe this difference. Similarly, both entity theorists and incremental theorists were far more skeptical of an extreme stretch, although those who viewed extremely rugged Mitsubishi shades were less accepting overall $\left(\mathrm{M}_{\text {Entity-Jeep }}=3.11\right.$ and $\mathrm{M}_{\text {Incremental-Jeep }}=3.05$ versus $\mathrm{M}_{\text {Entity-Mitsu }}=1.56$ and $\left.\mathrm{M}_{\text {Incremental-Mitsu }}=1.58\right)$. More importantly, implicit theory determines how accepting respondents were of a moderate stretch for both Jeep $\left(\mathrm{M}_{\text {Incremental-Jeep }}=3.74 \mathrm{vs.} \mathrm{M}_{\text {Entity-Jeep }}=\right.$ $2.84 ; \mathrm{t}(200)=2.73, p<.01)$ and Mitsubishi $\left(\mathrm{M}_{\text {Incremental-Mitsu }}=3.06\right.$ vs. $\mathrm{M}_{\text {Entity-Mitsu }}=2.25$; $\mathrm{t}(200)=2.45, p<.01)$. This pattern (see Figure 3) suggests perceptions of fit for brand extensions that stretch a particular trait (ruggedness) are determined in large part by one's implicit theory, which can be situationally steered to be more flexible and accommodating.

Insert Figure 3 about here

In Study 2, the combination of a personality and physicality stretch was too much. Here, perceptions are driven solely by the ruggedness trait, and, consistent with Hypothesis 4, even incremental theorists can reject a brand personality stretch that is seen as too extreme. These results also support both Hypotheses 2 and 3, such that those primed to 
believe change is common and acceptable (incremental theory prime) were more accepting of a moderate stretch (greater perceived fit) than those primed to believe traits are fixed and unchanging (entity theory prime). An identical pattern of results was found for predictions of brand extension success.

\section{Discussion}

The results of Study 3 demonstrate how implicit theories impact perceptions of fit between a parent brand and an extension that differs in terms of its personality. In this study, we focused on personality differences within a single dimension - ruggedness. We demonstrate how situationally activating an incremental theory orientation enhances the perceived fit when a brand extension stretches in terms of the change in personality it attempts relative to the parent brand. Compared to those primed to take on an entity theory orientation, those primed towards an incremental theorist orientation saw a much better fit between the parent brands and extensions that differed to a greater extent solely on a single personality dimension.

This study has important implications for marketing managers as persuasive communication can either lead consumers to believe that a brand is more malleable or more fixed with respect to its traits. Knowing that implicit theories can be activated and thus affect the evaluations of brand extensions contributes to our understanding of branding in general, as well as brand personality and brand extensions in particular. However, simply because people may be incremental theorists or primed to be more flexible toward accepting a brand's changes does not mean the malleability of brands is limitless. Our results show that even for those primed to take an incremental theory orientation, too far of a stretch (e.g. extreme) may be rebuffed. Of course, what is seen as extreme for Mitsubishi 
differs from what is seen as extreme for Jeep, which reminds brand managers they must understand consumers' perceptions regarding their brands personality when considering extensions.

In Study 3, we were careful to utilize parent brands known for competing in only one category (cars) and tested extensions in only one category (sunglasses). We also insured all that varied was the positioning on a single personality dimension, ruggedness. We varied the degree of trait change such that the resultant brand extensions were relatively acceptable to both incremental theorists and entity theorists (near stretch), were relatively unacceptable to both groups (extreme stretch), and fell somewhere in between (moderate stretch). This in-between space is the area of interest as it reveals the moderating effect of implicit theory on acceptable malleability of a brand's personality and hence an extension's perceived fit.

\section{General Discussion}

Through three studies, we have demonstrated how the success of brand extensions can benefit from understanding and influencing consumers' implicit theories of the self. Our research suggests that consumers who believe brand traits are malleable are more accepting of brand extensions - those that are a stretch on personality dimensions - than consumers who believe traits are fixed. The implicit theories that determine whether traits are seen as malleable or fixed are dispositionally held and can be situationally primed (Study 1). Implicit theories affect the perceived fit based on congruence between the personality traits of the parent brand and the brand extension (Study 2). Through the use of persuasive communication marketers can influence consumers' implicit theory disposition and hence judgments of brand extensions (Study 3). Although implicit theories are able to 
increase the flexibility of the consumer regarding brand extendibility, there are limits even for those more favorably disposed to change (i.e., incremental theorists).

This work contributes to the existing literature in numerous ways. First, we have enriched the brand extension literature. Managers often take a product focus when examining extension fit. We must remember that like brand image, fit exists in the consumer's mind and both product characteristics and consumer characteristics affect perceptions of fit. We demonstrate that the consumer characteristic described as implicit theory orientation affects the evaluation of brand extensions in many ways. It affects brand extension acceptability (Study 1), personality trait congruence (Studies 2 and 3), judgments of fit (Studies 2 and 3), and perceptions of success (Study 3). We also have made a contribution to the brand personality literature. Aaker (1999) explored the self-expressive role of brands, demonstrating how usage situations, brand personality, and self-concept interact. In her work on the malleable self, Aaker argued that given different situational cues, preferences for brands can be expected to vary across usage situations. She accepted the brand's traits as fixed while considering the consumer's malleable. We offer evidence that consumers make inferences as to the malleability of the brand, suggesting that the traits associated with a particular brand are more flexible than previously acknowledged. We have made contributions to the social psychology literature on implicit theories by extending transference of implicit theories not only from the self to others but from the self to brands. We have also documented an under-explored boundary condition - the degree of trait change or "stretch." Taken together, this research offers managers a number of valuable insights into implicit theories of the self, how they operate, and their effect on the 
evaluation of brands and brand extensions. It also offers them a potential tool toward enhancing the marketing of brand extensions.

\section{Managerial Implications}

Our research provides a change in how managers might think about the problem of perceived fit for brand extensions. Fit, seen as a function of brand, product, category, and firm differences, is traditionally regarded as a fixed constant for a given parent brand and brand extension pair. The only option available to managers was to make the existing "fit" between a brand and its extension more salient. In our expanded conceptualization of fit, managers are less constrained than previous believed. They can also change the mindset of the consumer to make the same message more effective. This is a change from the traditional thinking that the advertising message is the variable that is manipulated and delivered to a fixed consumer. It is also unlike many other individual difference variables, which rely on managers identifying appropriate segments. Now the consumer's mindset becomes an additional controllable variable, and managers have an additional technique in their toolbox to increase a message's effectiveness.

There are often situations where marketing managers cannot modify their positioning, product characteristics, or brand personality. Managers can still increase acceptance of a brand extension if they recognize how to influence the consumers' implicit theory instead. It is important to remind the reader that although implicit theories are chronic, they can be situationally activated as well. Managerially, the fact that one implicit theory or the other can be activated has important implications for communication strategies, which may provide an avenue for easing the acceptance of brand extensions. Additionally, the firm does not need to focus consumers specifically on the traits they want 
accepted; communicating the malleability of the parent brand as a whole or even manipulating on the consumers' implicit theories regarding their individual traits will suffice. As shown in our studies, the manipulation can be subtle; it neither needs to involve the brand name (Study 1) nor directly mention the particular trait of interest (Studies 1 and 3). Avoiding this level of specificity might be useful if the firm wants to prime multiple dimensions of personality trait congruence. To this end, the power and flexibility associated with priming implicit theories has important real-world implications.

We have demonstrated that implicit theories are useful when managers want to make their parent brands more malleable in order to ease brand extension acceptance. However, there are many times when a brand manager may appreciate it when their brand personality is more fixed. For example, an entity orientation may protect a brand from equity dilution caused by unexpected events such as when a celebrity endorser who is an athlete tests positive for steroids. Promoting an entity orientation towards the brand on the ruggedness dimension may help shield the brand from negative fallout. If the perceptions of the core personality of the brand could be made more "fixed" during times of threat, then implicit theories would be an important tool for protecting a brand's existing equity. In sum, manipulating consumers' implicit theories should help permit brand extensions and repositioning efforts as well as prevent brand equity dilution.

This research is not without its limitations. Further research could also address differences in trait importance. Research by Plaks et al. (2005) suggests core beliefs are more important than marginal traits. This distinction may have an important impact on the brand extension literature, as core beliefs about a brand such as Coca-Cola, being "classic" and "American," may be more susceptible to implicit theories (i.e. seen as more fixed or 
malleable by opposing camps) than other less core traits such as "fizzy" and "sweet." An important next step in studying the impact of implicit theories on marketing concepts should include improving our understanding of what types of traits are more or less likely to be affected.

Although we have investigated implicit theories and their roles in brand extensions, the impact of how flexible or malleable an item's traits are seen as being can impact a number of other areas in consumer behavior. Certainly, celebrity endorsers who move from brand to brand may raise the ire of entity theorists who cannot make the associations between Tiger Woods and Nike clothing in addition to Tiger Woods and Buick automobiles and Tiger Woods and Accenture consulting. It may even be the case that one extension (Nike) reinforces the traits associated with the core brand (Tiger), which makes other endorsements less consistent. Future work could also examine the interrelation between change attempts, the degree of change, and the sequence of change.

We never think of individuals as not possessing a personality, but a new brand can be a relatively blank slate. One wonders how implicit theories would interact with the creation of a brand personality. Would entity theorists be quicker to set and choose a brand personality? Levy et al. (1997) found that entity theorists assigned significantly stronger traits to novel groups and endorsed stereotypes to a greater degree than did incremental theorists. This research may translate to a more efficient establishment of brand personality. Perhaps once established, personality set with a situationally primed entity orientation would be stronger or more consistently held than one arrived at through an incremental orientation. Alternatively, establishing a brand personality may mean growing or stretching traits from a "zero point" of no personality. If so, fostering an incremental 
theory may lead to a more efficient establishment of brand personality. Either way, implicit theory is a useful managerial tool in brand creation and extension and warrants further study. 


\section{TABLE 1}

STUDY 1 - PART I: BRAND EXTENDIBILITY

AND IMPLICIT THEORIES

DV: Average Number of Brand Extensions Deemed Appropriate

\begin{tabular}{ccc}
\hline \hline & Implicit Theory Orientation \\
& $\begin{array}{c}\text { Entity } \\
\text { Theorists } \\
(\mathrm{n}=64)\end{array}$ & $\begin{array}{c}\text { Incremental } \\
\text { Theorists } \\
(\mathrm{n}=61)\end{array}$ \\
\hline Total Number of Extensions & 1.53 & $2.77^{*}$ \\
Number of Extensions for & & \\
Dreyer's Ice Cream & 1.30 & $2.72^{*}$ \\
OshKosh B'Gosh Children's Clothing & 1.43 & $2.86^{*}$ \\
Sketchers Sneakers & 1.69 & $3.00^{*}$ \\
Nokia Cell Phones & 1.75 & $2.88^{*}$ \\
Paper Mate Pens & 1.51 & $2.41^{*}$ \\
\hline
\end{tabular}

$* \mathrm{p}<.01$ 
TABLE 2

STUDY 1 - PART II: BRAND EXTENDIBILITY

AND PRIMED IMPLICIT THEORIES

DV: Average Number of Brand Extensions Deemed Appropriate

\begin{tabular}{ccc}
\hline \hline & \multicolumn{2}{c}{ Implicit Theory Orientation } \\
Entity & $\begin{array}{c}\text { Theorists } \\
(\mathrm{n}=62)\end{array}$ & $\begin{array}{c}\text { Incremental } \\
\text { Theorists } \\
(\mathrm{n}=62)\end{array}$ \\
\hline Total number of Extensions & 1.30 & $1.89^{*}$ \\
Number of extensions for & & $1.80^{*}$ \\
Ivory Soap & 1.24 & $1.71^{*}$ \\
Starbucks Coffee & 1.16 & $2.16^{*}$ \\
Yamaha Motorcycles & 1.32 & $2.08^{*}$ \\
Nokia Cell Phones & 1.32 & $1.71^{*}$ \\
Paper Mate Pens & 1.32 & \\
\hline
\end{tabular}

$* \mathrm{p}<.01$ 
TABLE 3

STUDY 2: PARENT BRANDS AND EXTENSIONS

\begin{tabular}{|c|c|c|}
\hline \multicolumn{3}{|l|}{ Parent Brand: Subaru } \\
\hline \multicolumn{3}{|l|}{$\begin{array}{l}\text { Physical Trait: Engine Technology } \\
\text { Personality Trait: Ruggedness }\end{array}$} \\
\hline Brand Extension & $\begin{array}{l}\text { Physical } \\
\text { Congruence }\end{array}$ & $\begin{array}{l}\text { Personality } \\
\text { Congruence }\end{array}$ \\
\hline Jet Ski & $\mathrm{Y}$ & Y \\
\hline Kayak & $\mathrm{N}$ & Y \\
\hline Motorized Scooter & $\mathrm{Y}$ & $\mathrm{N}$ \\
\hline Skateboard & $\mathrm{N}$ & $\mathrm{N}$ \\
\hline \multicolumn{3}{|l|}{ Parent Brand: Tiffany \& Co. } \\
\hline \multicolumn{3}{|l|}{$\begin{array}{l}\text { Physical Trait: Sterling Silver } \\
\text { Personality Trait: Sophistication }\end{array}$} \\
\hline Brand Extension & $\begin{array}{l}\text { Physical } \\
\text { Congruence }\end{array}$ & $\begin{array}{l}\text { Personality } \\
\text { Congruence }\end{array}$ \\
\hline Silver Buckled High Heel Shoes & $\mathrm{Y}$ & $\mathrm{Y}$ \\
\hline Leather High Heel Shoes & $\mathrm{N}$ & $\mathrm{Y}$ \\
\hline Silver Buckled Work Flats & $\mathrm{Y}$ & $\mathrm{N}$ \\
\hline Leather Work Flats & $\mathrm{N}$ & $\mathrm{N}$ \\
\hline
\end{tabular}


TABLE 4

STUDY 2: BIG 5 BRAND PERSONALITY SCORES

\begin{tabular}{|c|c|c|c|c|c|}
\hline Parent Brand & Rugged & Sincere & Excited & Competent & Sophisticated \\
\hline Tiffany & 1.5 & 2.9 & 3.4 & 4.0 & 4.4 \\
\hline Subaru & 3.9 & 3.1 & 3.4 & 3.4 & 2.5 \\
\hline Brand Extension & Rugged & Sincere & Excited & Competent & Sophisticated \\
\hline Tiffany silver high heel & 1.3 & 2.2 & 2.9 & 3.3 & 4.0 \\
\hline Tiffany leather high heel & 1.4 & 2.3 & 2.9 & 3.2 & 4.2 \\
\hline Tiffany silver work flat & 1.4 & 2.3 & 3.1 & 3.4 & 3.1 \\
\hline Tiffany leather work flat & 1.7 & 2.4 & 2.7 & 2.7 & 2.7 \\
\hline Subaru jet ski & 3.9 & 2.6 & 3.5 & 3.5 & 2.6 \\
\hline Subaru kayak & 4.2 & 3.0 & 3.6 & 3.4 & 2.6 \\
\hline Subaru motorized scooter & 2.7 & 3.0 & 3.2 & 2.6 & 2.5 \\
\hline Subaru skateboard & 3.6 & 2.5 & 3.4 & 2.4 & 2.0 \\
\hline
\end{tabular}


FIGURE 1

STUDY 2: 2-WAY INTERACTION BETWEEN IMPLICIT THEORY AND PERSONALITY CONGRUENCE ON PERCEPTIONS OF FIT

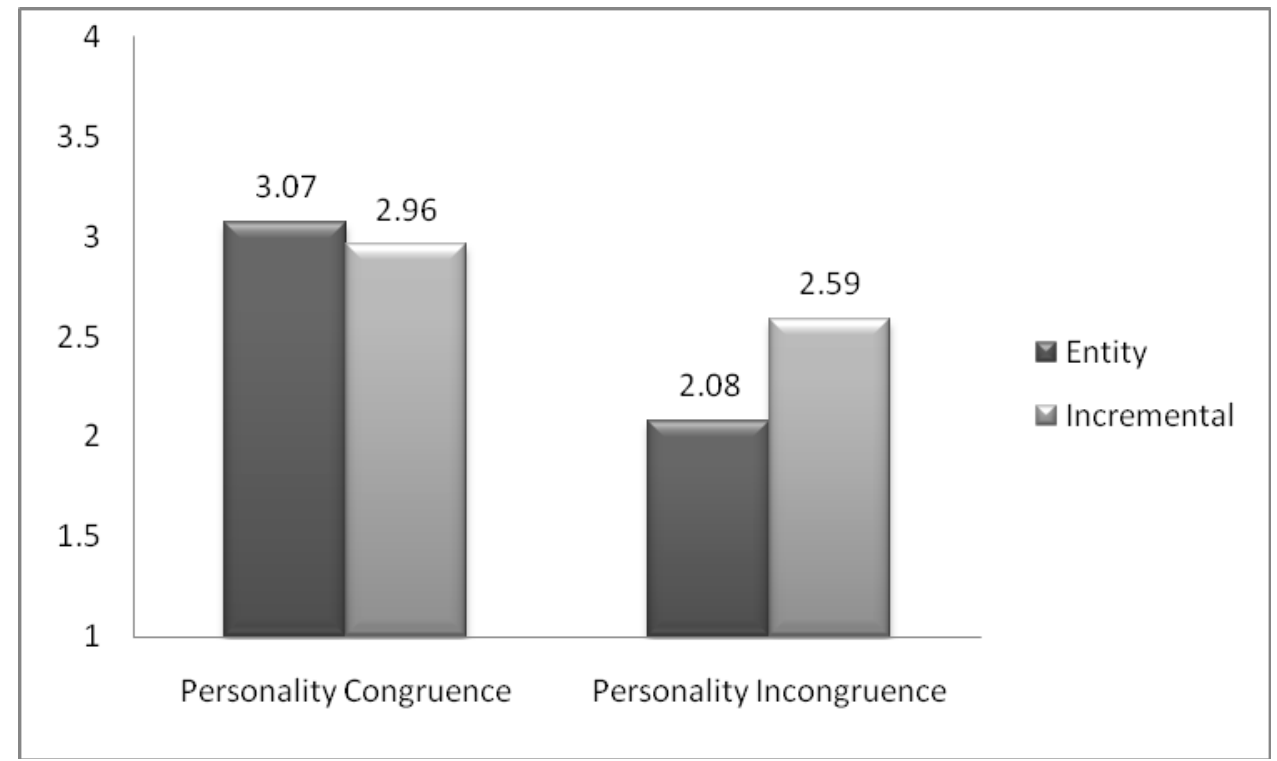


FIGURE 2

STUDY 2: 3-WAY INTERACTION BETWEEN IMPLICIT THEORY, PHYSICAL CONGRUENCE, AND PERSONALITY CONGRUENCE ON PERCEPTIONS OF FIT

PANEL A

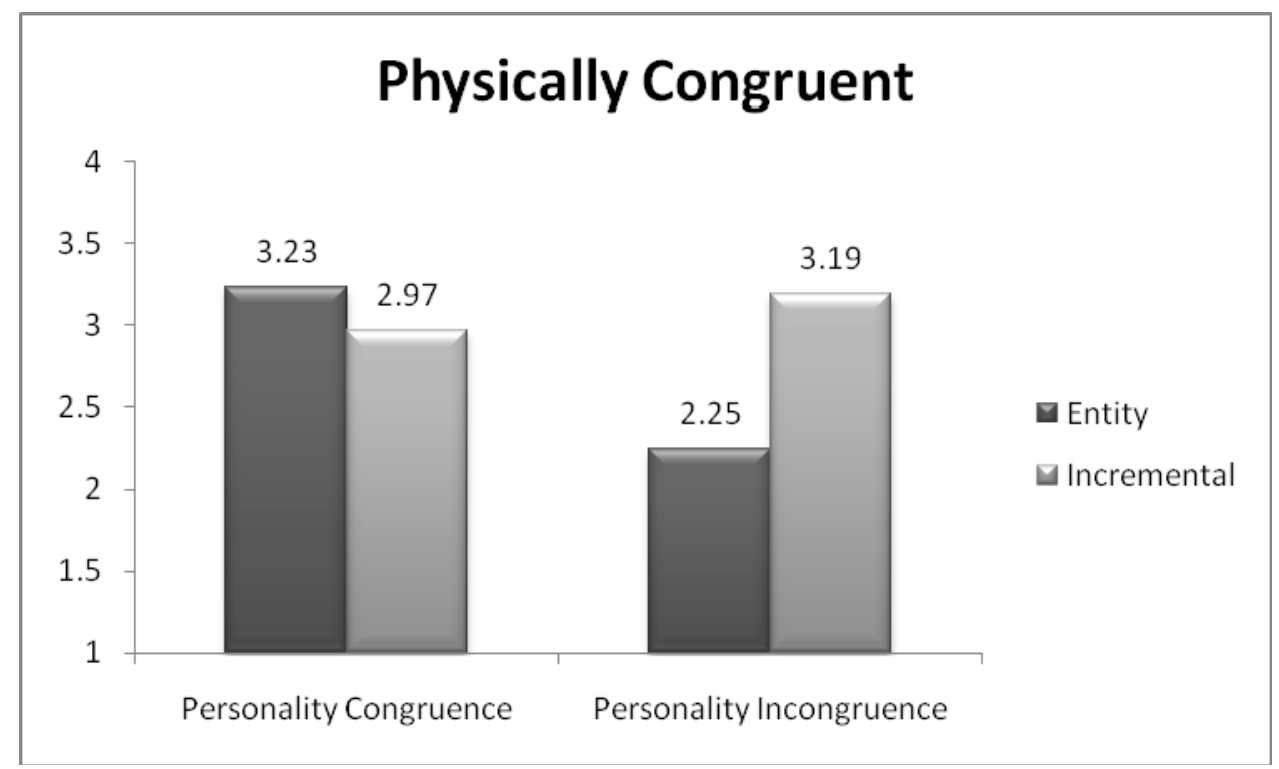

PANEL B

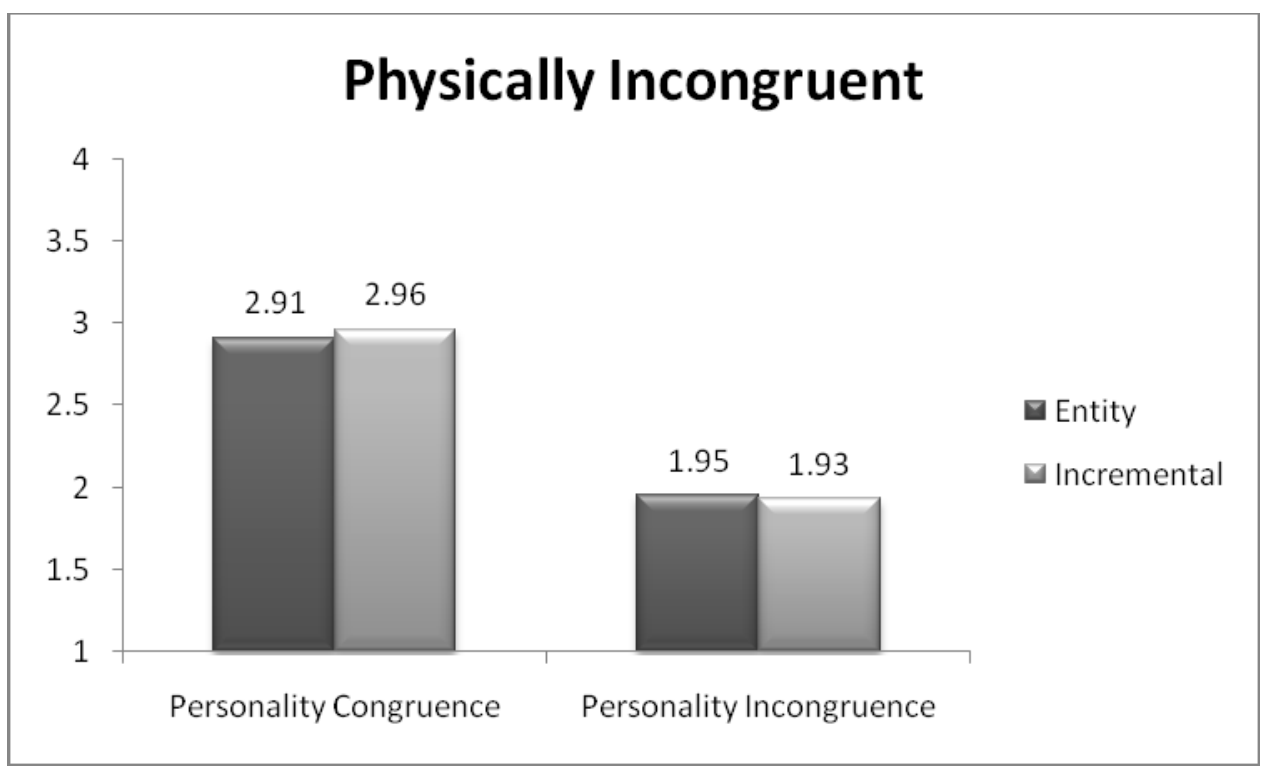


FIGURE 3

STUDY 3: INTERACTION OF BRAND STRETCH AND IMPLICIT THEORY ON PERCEPTIONS OF FIT
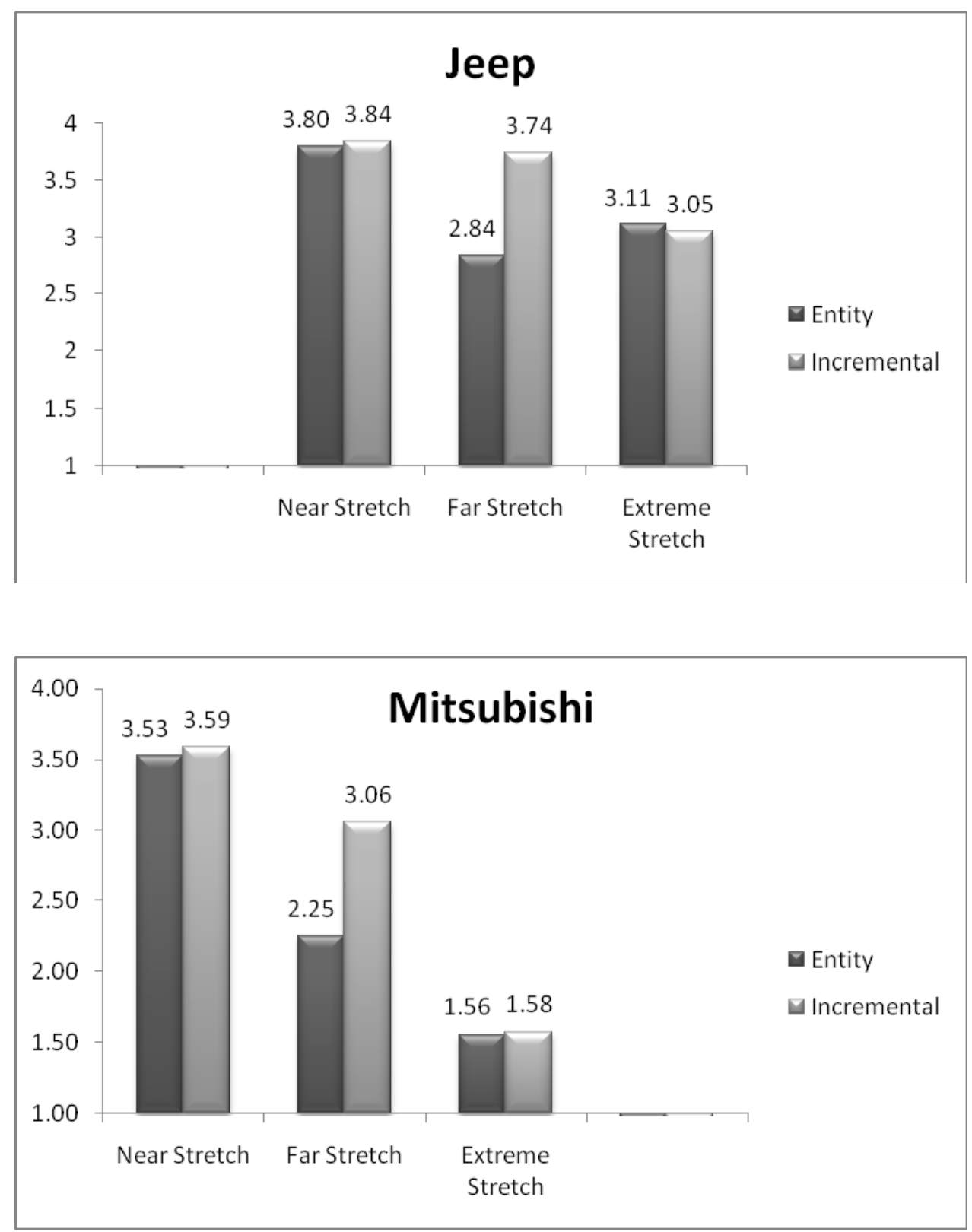


\section{REFERENCES}

Aaker, David A. and Kevin L. Keller (1990), "Consumer Evaluations of Brand Extensions," Journal of Marketing, 54 (January), 27-41.

Aaker, Jennifer (1997), “Dimensions of Brand Personality,” Journal of Marketing Research, 34 (August), 347-57.

(1999), "The Malleable Self: The Role of Self-Expression in Persuasion," Journal of Marketing Research, 36 (February), 45-57.

Ahluwalia, Rohini (2008), "How Far Can a Brand Stretch? Understanding the Role of SelfConstrual," Journal of Marketing Research, 45 (June), 337-50.

Austin, James T. and Jeffrey B. Vancouver (1996), "Goal Constructs in Psychology: Structure, Process, and Content," Psychological Bulletin, 120 (November), 338-75.

Batra, Rajeev, Donald R. Lehmann, and Dipiner Singh (1993), “The Brand Personality Component of Brand Goodwill: Some Antecedents and Consequences." in Brand Equity and Advertising: Advertising's Role in Building Strong Brands, ed. David A. Aaker and Alexander Biel, Hillsdale, NJ: Lawrence Erlbaum Associates, Inc., 8396.

Boush, David and Barbara Loken (1991), "A Process-Training Study of Brand Extension Evaluation,” Journal of Marketing Research, 28 (February), 16-28.

Bridges, Sheri, Kevin Lane Keller, and Sanjay Sood (2000), "Communication Strategies for Brand Extensions: Enhancing Perceived Fit by Establishing Explanatory Links," Journal of Advertising, 29(Winter) 1-11.

Briggs, Steven (1992), "Assessing the Five-Factor Model of Personality Description," Journal of Personality, 60(2), 253-93.

Broniarczyk, Susan M. and Joseph W. Alba (1994), "The Importance of the Brand in Brand Extension," Journal of Marketing Research, 31 (May), 214-28. 
Butler, Ruth (2000), "Making Judgments About Ability: The Role of Implicit Theories of Ability in Moderating Inferences from Temporal and Social Comparison Information," Journal of Personality and Social Psychology, 78 (May), 965-78.

Chiu, Chi-yue, Carol S. Dweck and Jennifer Yuk-yue Tong, and Jeanne Ho-ying Fu (1997), "Implicit Theories And Conceptions of Morality," Journal of Personality and Social Psychology, 73 (November), 923-40.

Chiu, Chi-yue, Ying-yi Hong, and Carol S. Dweck (1997), "Lay Dispositionism and Implicit Theories of Personality," Journal of Personality and Social Psychology, 73 (July), 19-30.

Desai, Kalpesh K. and Kevin L. Keller (2002), “The Effects of Ingredient Branding Strategies on Host Brand Extendibility," Journal of Marketing, 66 (January), 73-93.

Diamantopoulos, Adamantios, Gareth Smith, and Ian Grime (2005), "The Impact of Brand Extensions on Brand Personality: Experimental Evidence," European Journal of Marketing, 39(1/2), 129-149.

Dweck, Carol S., Chi-yue Chiu and Ying-yi Hong (1995a), "Implicit Theories and Their Role in Judgments and Reactions - a World from 2 Perspectives," Psychological Inquiry, 6 (4), 267-85.

Dweck, Carol S., Chi-yue Chiu and Ying-yi Hong (1995b), "Implicit Theories: Elaboration and Extension of the Model," Psychological Inquiry, 6 (4), 322-333.

Gürhan-Canli, Zeynep (2003), “The Effect of Expected Variability of Product Quality and Attribute Uniqueness on Family Brand Evaluations," Journal of Consumer Research, 30(January) 105-114.

Gürhan-Canli, Zeynep and Durairaj Maheswaran (1998), “The Effects of Extensions on Brand Name Dilution and Enhancement," Journal of Marketing Research, 35 (November), 464-73.

Hong, Ying-yi, Sheri R. Levy, and Chi-yue Chiu (2001), "The Contribution of the Lay Theories Approach to the Study of Groups," Personality and Social Psychology Review, 5 (May), 98-106. 
Keller, Kevin Lane (1993), "Conceptualizing, Measuring, and Managing Customer-based Brand Equity," Journal of Marketing, 57(January), 1-22.

Keller, Kevin Lane and David A. Aaker (1992), “The Effects of Sequential Introduction of Brand Extensions," Journal of Marketing Research, 29 (February), 30-50.

Kirmani, Amna, Sanjay Sood and Sheri Bridges (1999), "The Ownership Effect in Consumer Responses to Brand Line Stretches," Journal of Marketing, 63 (January), 88-101.

Klink, Richard R. and Daniel C. Smith (2001), "Threats to the External Validity of Brand Extension Research,” Journal of Marketing Research, 38 (August), 326-35.

Levy, Sheri R., Steven J. Stroessner, and Carol S. Dweck (1998), "Stereotype Formation and Endorsement: The Role of Implicit Theories," Journal of Personality and Social Psychology, 74 (June), 1421-36.

Loken, Barbara and Deborah Roedder John (1993), "Diluting Brand Beliefs: When Do Brand Extensions Have a Negative Impact?" Journal of Marketing, 57 (July), 7184.

Mao, H. and H.S. Krishnan (2006), "Effects of Prototype and Exemplar Fit on Brand Extension Evaluations: A Two-Process Contingency Model," Journal of Consumer Research, 33(1), 41-49.

Martin, Ingrid M. and David W. Stewart (2001), "The Differential Impact of Goal Congruency on Attitudes, Intentions, and the Transfer of Brand Equity," Journal of Marketing Research, 38 (November), 471-84.

Morrin, Maureen (1999), "The Impact of Brand Extensions on Parent Brand Memory Structures and Retrieval Processes," Journal of Marketing Research, 36 (November), 517-25.

Morgan, George A., Jeffrey A. Gliner, and Robert John Harmon (2005), Understanding and Evaluating Research in Applied and Clinical Settings, Lawrence Erlbaum Associates: Mahwah, NJ. 
$\mathrm{Ng}, \mathrm{S}$ and Michael J. Houston (2006), "Exemplars or Beliefs? The Impact of Self-review on the Nature and Relative Influence of Brand Associations," Journal of Consumer Research, 32(4) 519-529.

Nunnally, Jum C. (1978), Psychometric Theory, New York: McGraw-Hill Publishing Company.

Ourusoff, Alexandra, Michael Ozanian, Paul B. Brown, and Jason Starr (1992), "What's in a Name? What the World's Top Brands are Worth," Financial World (September 1), 32-49.

Park, C. Whan, Sandra J. Milberg, and Robert Lawson (1991), "Evaluation of Brand Extensions: The Role of Product Level Similarity and Brand Concept Consistency," Journal of Consumer Research, 18 (September), 185-93.

Plaks, Jason E., Heidi Grant, and Carol S. Dweck (2005), "Violations of Implicit Theories and the Sense of Prediction and Control: Implications for Motivated Person Perception," Journal of Personality and Social Psychology, 88 (2), 245-62.

Plummer, Joseph T. (1985), “How Personality Makes a Difference,” Journal of Advertising Research, 24 (6), 27-31.

Rook, Dennis W. (1985), “The Ritual Dimension of Consumer Behavior," Journal of Consumer Research, 12 (December), 251-64.

Smith, Daniel C., and C. Whan Park (1992), "The Effects of Brand Extensions on Market Share and Advertising Efficiency,” Journal of Marketing Research, 29 (August), 296-313.

Tauber, Edward M. (1988), "Brand Leverage: Strategy for Growth in a Cost-Controlled World," Journal of Advertising Research, 28 (Aug/Sept), 26-30.

Van Osselaer, Stijn M. J. and Joseph W. Alba (2003), "Locus of Equity and Brand Extension,” Journal of Consumer Research, 29 (March), 539-50.

Völckner, Franziska and Henrik Sattler (2006), "Drivers of Brand Extension Success," Journal of Marketing, 70 (April), 18-34. 
Zhang, Shi and Sanjay Sood (2002), “'Deep' and 'Surface' Cues: Brand Extension Evaluations by Children and Adults," Journal of Consumer Research, 29 (June), $129-41$. 


\section{Introducing MITSUBISHI brand sunglasses}

At Mitsubishi, we are committed to consistency and unwavering steadfastness. Ask yourself how our rock-solidness can fit your lifestyle. Your personality and ideals stay the same and Mitsubishi stays there with you. Mitsubishi now has sunglasses for what you do.

These are not just sunglasses - they're protection from the elements. From hiking in the Rockies to fishing off the Baja coast - what protects you should be built to endure and as rugged as you are. Anywhere that adventure takes you, your gear should be ready to handle. Mitsubishi, we make sunglasses for every adventure. 